\title{
中国龍游洞窟の地盤比抵抗についての考察
}

\author{
谷 本 親 伯* 石田祐 也** 小泉圭 吾** \\ 李 黎** 上 出定 幸 ${ }^{* *}$ 外 屋 直 ${ }^{* * * *}$

\section{The Consideration about Ground Electric Resistivity at the Longyou Grottoes of China}

\author{
by \\ Chikaosa TAnimoto ${ }^{*}$, Yuya Ishida ${ }^{* *}, \operatorname{Keigo~Kolzumi~}^{* *}, \mathrm{Li} \mathrm{Li}^{* *}$, \\ Sadayuki Kamide ${ }^{* * *}$ and Tadashi Masuya ${ }^{* * * *}$
}

\begin{abstract}
The authors have been applying the Electric Resistivity Method (ERM) to heritage sites since 1995. ERM is one of the non-destructive prospecting techniques which is conveniently employed in the geotechnical field. Information obtained through ERM suggests rock properties, characteristics of discontinuities such as faults, joints and in-bedding materials, water content, and so on. The objective site of this paper is the Longyou Grottoes, situated in the central west of Zhejiang Province, China. 24 large caves, which are presumed to have been constructed around 2300-2400 years ago, were found by chance in 1992, and 5 of them were drained in full scale. The distribution of local lineaments was analyzed in terms of a satellite image, then electric resistivity around the caves, mineral components of the rock formation and cave walls, water qualities of the river, ground surface, and seepage into the caves were investigated. In conclusion, low resistivity zone shows the deterioration of rock formation, and the control of surface water should be materialized as soon as possible.
\end{abstract}

Key words : Heritage, Electric resistivity, Longyou Grottoes, Mineral components, Water

\section{1 緒言}

物理探査を用いた遺跡調查は，日本国内に打いても多 く実施されている.1)国内の埋没遺跡は，地盤の比較的浅 い位置にあり，各探査に求められることは，地表浅部の 地盤状況を把握することであると言える。また，その目 的は, 発掘調查の予備調査として用いられることが多い. 本研究では中国の石造地下洞窟遺跡に対して, その保存 という観点から, 比抵抗探査を実施し, 洞窟とその周辺 の地盤状況を考察する. 比抵抗探査により, 地下数 $10 \mathrm{~m}$ までの地盤比抵抗を把握することで, 既往の調査に加え 有益な情報を取得することを目的としている。

地盤の比抵抗の考察に際して重要となるのは, 岩石供 試体の比抵抗とそれに影響するパラメータとの関係であ る. 近年の研究や報告では, 岩石供試体の比抵抗と水分 飽和度, 間隙水の比抵抗, 間隙率等のパラメータとの関係 が供試体を用いた試験によって多く述べられている.2) 4) 自然の地盤比抵抗はその地質背景や地盤状況によって変 化し, 室内試験から得られる岩石固有の比抵抗特性に加 え, 現地地盤の情報を考慮した上で地盤比抵抗を考察す る必要がある。そこで本研究では, 石造遺跡を構成する 砂岩層の地盤の比抵抗特性を，既往の研究 5) や鉱物分析
結果, ボーリング調査結果等の現地地盤情報を基に考察 する.

\section{2 研 究 対 象 地}

本研究の対象地は，上海から南西へ約 $300 \mathrm{~km}$ ，中国南 東部浙江省にある中国龍游洞窟である（Fig. 1)，洞窟は 1992 年に 24 個の地下洞窟群として発見された。発見当 時, 洞窟は溜池として存在しており, 現在ではそのうち 5 つの洞窟に扎いて水と泥が排出され，観光用に公開さ れている. 5 つの洞窟の形状には特徵があり, 洞窟天井

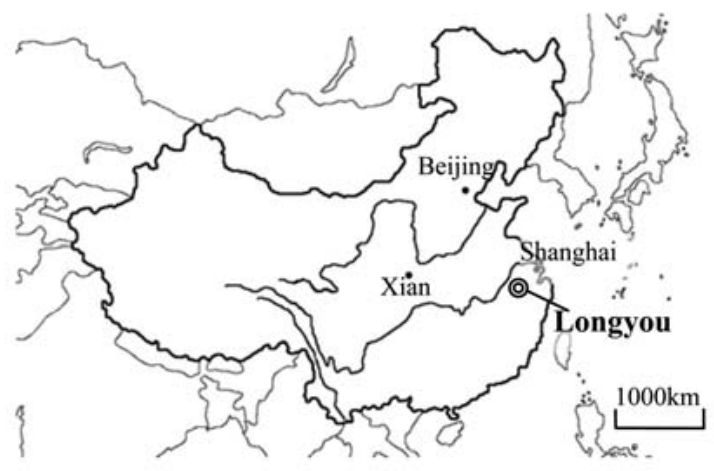

Fig. 1 Location of Longyou.

$\dagger \quad$ 原稿受理 平成 19 年 2 月 14 日 Received Feb. 14, 2007 @ 2008 The Society of Materials Science, Japan

* 正 会 員 大阪大学大学院工学研究科地球総合工学専攻 \%565-0871 吹田市山田丘, Dept. of Global Architecture, Graduate School of Eng., Osaka, Univ., Yamadaoka, Suita, 565-0871

**大阪大学大学院工学研究科地球総合工学専攻 =565-0871 吹田市山田丘, Dept. of Global Architecture, Graduate School of Eng., Osaka, Univ., Yamadaoka, Suita, 565-0871

*** 正会員 (株オーデックス †532-0003 大阪市淀川区宮原, ODEX CO., Ltd., Yodogawa-ku, Osaka, 532-0003

****ハハチック(株)干532-0003大阪市淀川区宮原, HYTEC CO., Ltd., Yodogawa-ku, Osaka, 532-0003 
付近に入り口があり，入り口から離れるほど天井は傾斜 して低くなる四角錘のような形をしている（Fig. 2 参照. 天井は南から北へ低くなっている.). 天井の傾斜角度は 洞窟によって差異はあるが，20〜 $45^{\circ}$ であり，地層の傾 斜や割れ目に沿って掘削されたと考えられている。洞窟 内には石柱と池が存在し，石柱の断面がほぼ二等辺三角 形となっている．洞窟の全ての壁面および天井部に錅 (のみ) の痕があり，その方向は全ての洞窟と柱において 共通の傾向が認められる。洞窟群が何のために掘削され たものなのかは，現在も調查中であり，またその建造時 代も 2000 年以上前であると推測されているが，科学的 根拠とはまだ確認し得ていない，点越の戦争時に使われ たものであるという説や貯蔵庫，石材採取場所などとい う考えも挙がっている.

龍游洞窟は, 盆地内を北東流する河川からの地下水供 給があり，また洞窟周辺には溜池が築造されている箇所 も多く，洞窟は湿潤状態にある。そのため龍游洞窟では， 地下水に起因する岩盤の風化が生じている。地下水が洞 窟地盤に浸透することで, 浸食などの物理的風化が生じ る。また岩石に酸化・水和・溶脱などによる成分変化が 生じ，粘土鉱物が増えるという化学的風化も生じている。 また洞窟内では，地下水に溶解した塩類が壁面に析出す る塩害も観察できる。このような風化の進行が著しいこ とから，石造遺跡として今後保存していく上で，早急な 対応が必要である。そのために，洞窟周辺地盤の比抵抗 から洞窟地盤特性を把握することが必要となる。

\section{3 龍 游 の 気 候}

龍游地域は，亜熱帯季節風気候に属し，梅雨（6月） の温湿度は非常に高い。年平均気温は $17.3^{\circ} \mathrm{C}$, 月別平均 では 7 月に最高の $28.7^{\circ} \mathrm{C} ， 1$ 月に最低の $5.4^{\circ} \mathrm{C}$ とってお り，年間の気温変動が大きい。年平均相対湿度は $79 \%$ と 非常に高く，特に梅雨（6月）の相対湿度が $82 \%$ となっ ている。年間降雨量は $1843 \mathrm{~mm}$ で，特に 3 月から 6 月に 集中的に雨が降る.

\section{4 龍游洞窟周辺の地形と地質}

龍游洞窟が位置する中国南東部の大局的な地形配列は 地質構造に支配され，山脈や盆地，低地の配列は断裂带 と同じ北東一南西方向に伸びている，龍游洞窟は，算江 に並走する北東一南西方向の断裂帯に挟まれた金兓盆地

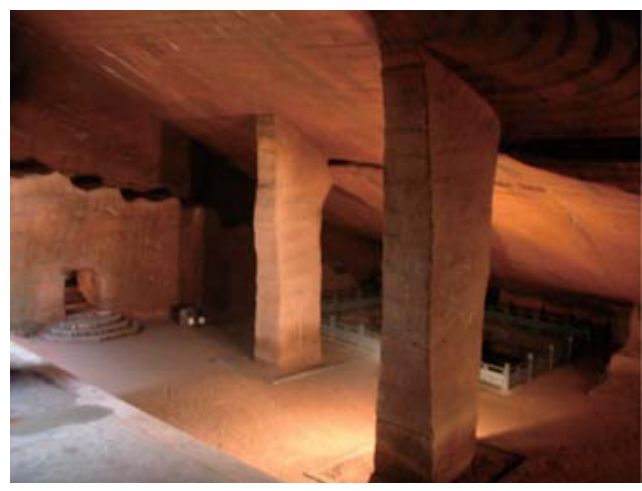

Fig. 2 Characteristic Ceiling and Columns in Cave 2
のほぼ中央に位置する。標高 $50 \sim 60 \mathrm{~m}$ 程度の丘陵の南 端部にあり，更新・完新統が狭在していることが多い.

龍游洞窟は，河川の水が四方の丘陵から集まって打り， 周辺には多数の溜池が点在する。南側には倠江が流れ， 洞窟上部にも溜池が造成されており，地盤は地下水の多 い状態である。基盤地質は中生代白亜系の金華組からな る単一地層であるが，新生代第四紀の未固結堆積物が分 布する箇所も見られる。

Fig. 3 に龍游洞窟周辺の衛星画像からリニアメントを 抽出した四を示す。衛星画像は，ASTER データであり， 分解能は $15 \mathrm{~m} \times 15 \mathrm{~m}$ である. Fig. 3 の, 赤色は植生, 青色は水域を示す。この罒から水域が盆地全体に広く分 布していることがわかる。また，南北の丘陵には断層と 考えられる多くのリニアメント (図線) が見られ，瞿江 も断層活動を受けて蛇行している様子がわかる。リニア メントの走行は断裂帯と同様の北東一南西方向（実線）

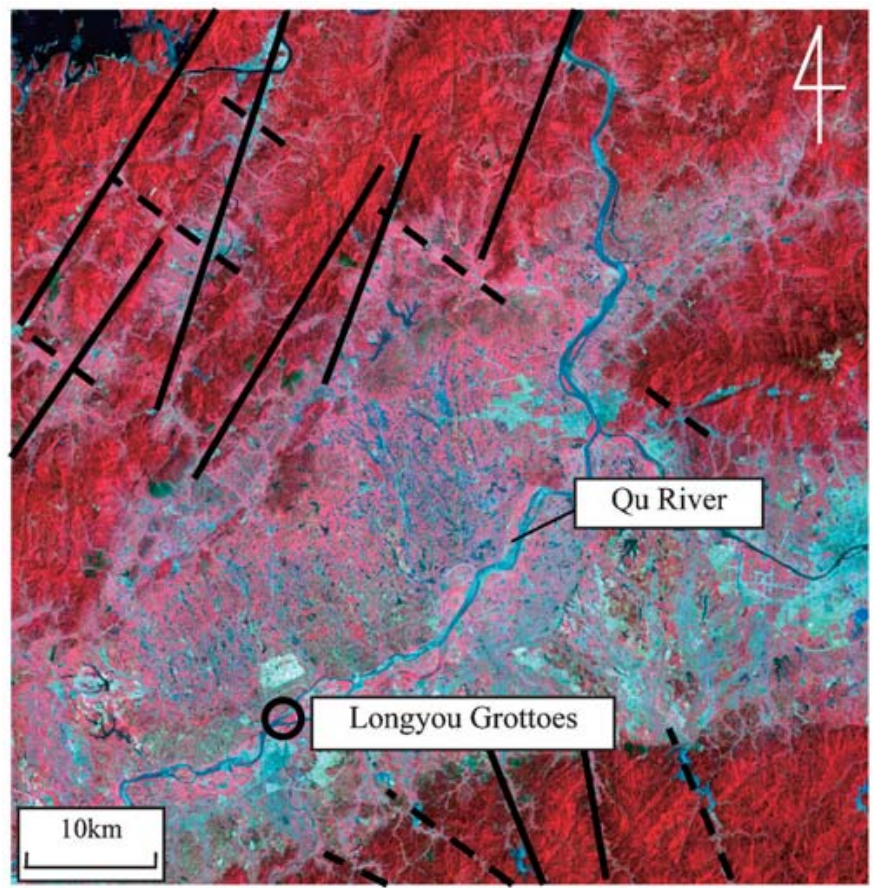

Fig. 3 Satellite Image through ASTER.

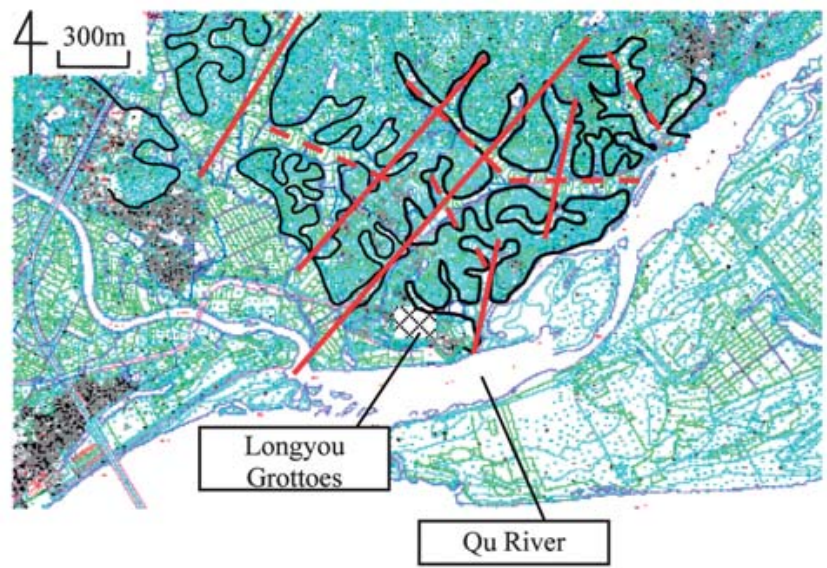

Fig. 4 Topography around Longyou Grottoes. 
に加え，それに直交する北西-南東方向のものも抽出でき る。衛星画像から，断層に沿った地下水・表流水の動き が考えられ，眐江の走行と同様に北から南へ流動し，盆 地に集水していると考えられる.

Fig. 4 に龍游周辺の地形図を示す。この地形図に扔い て，断裂線と考えられる遷急線を抽出し，リニアメント として記した。 これよりリニアメントの走向が北東一南 西方向 (実線) や北西一南東方向 (点線) のものが多く 見られる。過去の断層運動が，洞窟周辺地盤に影響して おり，また洞窟周辺に多くの層理・節理面が同一走行で 発達していると考えられ，広域での水系の走行同様，洞 窟周辺に打いても扎よそ北から南への地下水の移動が考 えられる。

次に龍游洞窟を構成する砂岩の物性に関して, 洞窟 1 , 2,3 で採取した砂岩試料について測定した結果を Table $1^{6)}$ に示す。それぞれの採取場所は，洞窟 1 では洞窟床面か ら数 $\mathrm{m}$ 掘った位置, 洞窟 2 , 洞窟 3 では北側壁面である. なお試料は層序から, 同年代の砂岩であることがわかっ ており，各洞窟を代表する試料と言える。測定時の試料 は非常に湿潤な現地砂岩に比べ，乾燥化が進んでいると 考えられる。測定方法を以下に示す。

（1）自然状態の試料の空中重量を測定後，試料を 72 時間以上水に浸す。

（2）強制湿潤状態の水中重量を測定する.

（3）試料表面の水を拭き取り，強制湿潤状態の空中重 量を測定する.

(4) 試料を乾燥炉に入れ，80〜 $110^{\circ} \mathrm{C}$ の設定温度で 24 時間以上乾燥した後，デシケータで常温まで冷却 する。この強制乾燥状態の空中重量を測定する。

（5）サンプルの全体積を算出し， $60^{\circ} \mathrm{C}$ 下で 24 時間乾 燥した後，重量を測定する。

以上の方法で, 乾燥重量, 有効間隙率, 湿潤重量, 密 度を求める。

洞窟 $1 \sim 3$ の各洞窟の砂岩の密度は全て $2.1 \sim 2.2 \mathrm{~g}$ / $\mathrm{cm}^{3}$ であった。中生代の岩石の密度が，砂質岩：2.6 $2.8 \mathrm{~g} / \mathrm{cm}^{3}$, 泥質岩： $2.5 \sim 2.75 \mathrm{~g} / \mathrm{cm}^{3}$ であることから ${ }^{7)}$ 洞窟を構成する砂岩は低密度であることがわかる。これ より，龍游砂岩は間隙率が大きいことが考えられる。ま た，粒度分析では，主に砂で組成されており，次いでシ ルト，粘土であることがわかる。

砂岩の鉱物組成と含まれる鉱物量から，風化による砂 岩の組成変化を把握することができる，洞窟 $1 ， 2 ， 3 ， 4$
で採取した砂岩に対して，細粒分に含まれる粘土鉱物を 知るために定性・定量分析の X 線回折分析を行い，その 結果を Table 2 に示す.

含まれる鉱物の量について，石英は洞窟 $1 \sim 4$ の砂岩 ではあまり違いが見られず 37 ～47\%である.しかし，方 解石，斜長石，赤鉄鉱は洞窟によって含まれる量が異な る。斜長石の量は洞窟 2 の砂岩で $10 \%$ と少なく, 洞窟 1 , 4 の砂岩では，20\%以上となっている，方解石の量は洞 窟 1 および洞窟 3 の砂岩で $16 \%$ と多く，洞窟 2 および洞 窟 4 の砂岩では 6 ～7\% となっている．洞窟 3 の砂岩て は，赤鉄鉱も確認される，以上から，砂岩は風化により， 鉱物組成が様々に変化していることがわかる。

また，砂岩には粘土鉱物であるモンモリロナイトやイ ライトが含まれていることがわかる，粘土鉱物は，砂岩 が風化作用などを受け，変質したものである。中でも， モンモリロナイトは，洞窟 1 ～４砂岩全てに含まれて おり, 洞窟 3 の砂岩に扎いて最も含有量が多い.

モンモリロナイトは，膨潤性粘土鉱物の一つであり， 水中に浸すと層間に水が入り込む性質を持つ. ${ }^{8}$ 水分子が 層間に入り込むことで，体積が数倍から数十倍に増大す る現象が生じる。これが繰り返されることで，水分子は さらに結合力を強め，結晶水となる．結晶水はモンモリ ロナイトの層間隔を押し広げ，その結果岩石の間隙を増 大させ，強度を低下させる。

鉱物分析より，洞窟を構成する砂岩に含まれるモンモ リロナイトの量が最も多い洞窟 3 では，洞窟が地下水に さらされることで砂岩の間隙が増大し，強度が低下して いることが考えられる.

\section{5 洞窟地盤と水質}

Fig. 5 に 2002 年に現地で行われたボーリング調査結 果を示す。ボーリング位置は Fig. 6 に比抵抗測線位置と 併せて示すこととする. Fig. 5 において，A～D の表示 はボーリング調査実施時に含有砕石物量や，間隙量を基 に定性的に風化度を表したものであり，A が全風化層， $\mathrm{B}$ が強風化層, $\mathrm{C}$ が弱風化層, $\mathrm{D}$ が微風化一新鮮岩層を 示す。罒より, 洞窟地盤の地下水面が高い位置に存在し, 地下水面付近から前後数 $\mathrm{m}$ の層で風化が進んでいること がわかる，また，洞窟地盤に主体となって分布する地層 は，赤色中〜厚層の層状を呈する泥質粉砂岩（シルト質 砂岩）であり，含礫砂岩，泥岩が薄層状態で狭在してい る箇所も見られるものの，地層はほぼ一様である。

2004 年 9 月および 2005 年 9 月に実施した現地踏査か
Table 1 Sandstone Physicality of Longyou Grottoes.

\begin{tabular}{|c|c|c|c|c|c|}
\hline & $\begin{array}{l}\text { density } \\
(\mathrm{g} / \mathrm{cm} 3)\end{array}$ & $\begin{array}{c}\text { moisture content } \\
(\%)\end{array}$ & $\begin{array}{c}\text { effective porosity } \\
(\%)\end{array}$ & \multicolumn{2}{|c|}{$\begin{array}{c}\text { grading analysis } \\
(\%)\end{array}$} \\
\hline Cave 1 & 2.193 & $1.10 \%$ & $8.86 \%$ & $\begin{array}{l}0.075-\mathrm{mm} \text { (Sand) } \\
0.005-0.075 \mathrm{~mm} \text { (Silt) } \\
0-0.005 \mathrm{~mm} \text { (Clay) }\end{array}$ & $\begin{array}{l}32.40 \% \\
68.36 \% \\
6.23 \%\end{array}$ \\
\hline Cave 2 & 2.126 & $1.12 \%$ & $8.11 \%$ & $\begin{array}{l}0.075-\mathrm{mm}(\text { Sand }) \\
0.005-0.075 \mathrm{~mm} \text { (Silt) } \\
0-0.005 \mathrm{~mm} \text { (Clay) }\end{array}$ & $\begin{array}{c}68.66 \% \\
21.27 \% \\
6.25 \%\end{array}$ \\
\hline Cave 3 & 2.118 & $1.15 \%$ & $9.10 \%$ & $\begin{array}{l}0.075-\mathrm{mm} \text { (Sand) } \\
0.005-0.075 \mathrm{~mm} \text { (Silt) } \\
0-0.005 \mathrm{~mm} \text { (Clay) }\end{array}$ & $\begin{array}{c}69.18 \% \\
25.24 \% \\
7.87 \%\end{array}$ \\
\hline
\end{tabular}

Table 2 Results of X-ray Diffraction Analysis.

\begin{tabular}{|l|c|c|c|c|c|c|}
\hline & quartz & calcite & plagioclase & hematite & montmorillonite & illite \\
\cline { 2 - 7 } & $\mathrm{SiO}_{2}$ & $\mathrm{CaCO}_{3}$ & $\begin{array}{c}(\mathrm{Na}, \mathrm{Ca}) \mathrm{Al} \\
(\mathrm{Si}, \mathrm{Al})_{3} \mathrm{O}_{2}\end{array}$ & $\mathrm{Fe}_{2} \mathrm{O}_{3}$ & $\begin{array}{r}\mathrm{Ca}_{2,2}(\mathrm{Al}, \mathrm{Mg})_{2} \mathrm{Si}_{4} \mathrm{O}_{10} \\
(\mathrm{OH})_{2} \cdot 4 \mathrm{H}_{2} \mathrm{O}\end{array}$ & $\begin{array}{c}\left(\mathrm{K}_{3} \mathrm{H}_{3} \mathrm{O}\right) \mathrm{Al}_{2} \\
\mathrm{Si}_{3} \mathrm{AlO}_{10}(\mathrm{OH})_{2}\end{array}$ \\
\hline Cave 1 & $47 \%$ & $16 \%$ & $21 \%$ & & $14 \%$ & $18 \%$ \\
\hline Cave 2 & $41 \%$ & $6 \%$ & $10 \%$ & & $16 \%$ & \\
\hline Cave 3 & $37 \%$ & $16 \%$ & $15 \%$ & $10 \%$ & $21 \%$ & \\
\hline Cave 4 & $46 \%$ & $6 \%$ & $28 \%$ & & $14 \%$ & $3 \%$ \\
\hline
\end{tabular}




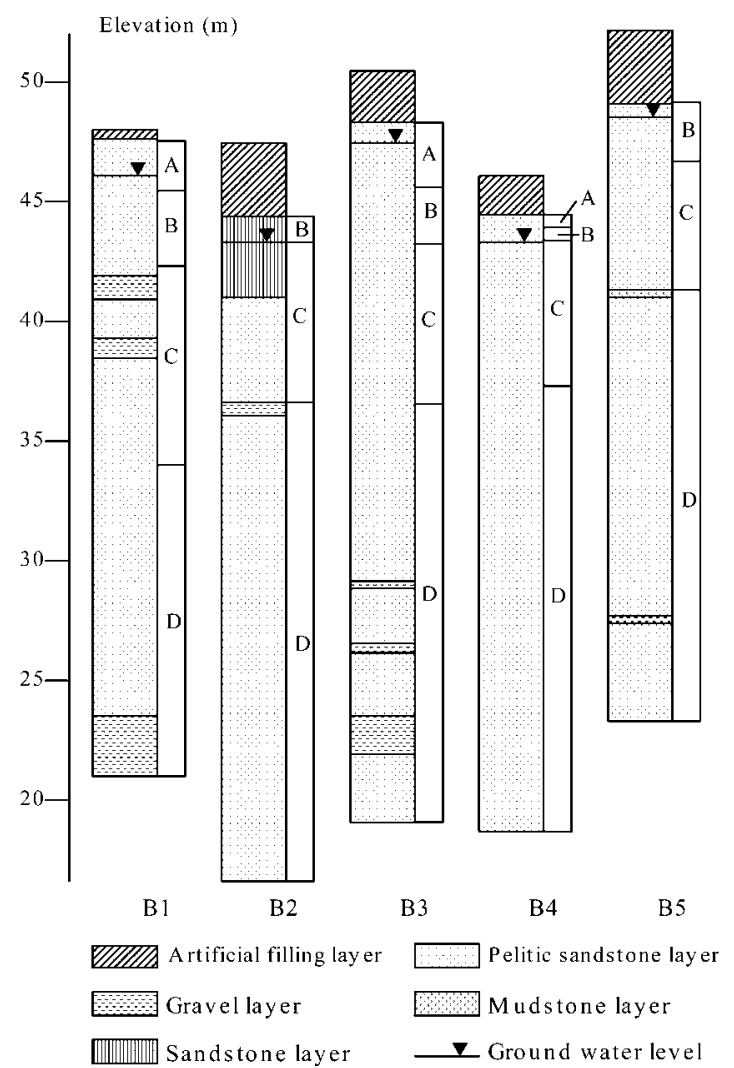

Fig. 5 Results of Boring Exploration (2002).

ら, 未排水の洞窟において, 天井部が崩落している箇所 や，割れ目が発達している箇所も多数確認できた.

排水されている 5 つの洞窟は全て地下水面以下に存在 し, 内部はほとんどの壁および天井部が水分で湿ってお り，割れ目も多く存在している。特に洞窟 2 および洞窟 3 の天井部や北側・西側の壁では，水が滴り落ちる筒所 もあるほど洞窟は地下水の影響を受けている。洞窟 2,3 の北側では，炭酸塩の析出も確認できる．洞窟観察から， Fig. 5 の A および B 層に位置する天井部や北側壁面に おいて顕著に現れている。

次に, 洞窟周辺の水質について述べる. Table 3 に比 抵抗探査に大きく関連する周辺水の比抵抗を測定した結 果を示す．比抵抗の測定にはマルチ水質モニタリングシス テムU-20XD (HORIBA製) を用いた. Table 3 より, 洞窟 内部の溜池の水 (in Caves) や, 天井からの浸透水, 隹江 の水は全て $50 \Omega \mathrm{m}$ 以下の低い比抵抗であることがわかる.

Table 3 Resistivity of Longyou Water.

\begin{tabular}{|c|c|c|c|}
\hline Sampling Point & COND(S/m) & Resistivity $(\Omega \mathrm{m}$ & Sampling date \\
\hline Artificial pond in Cave 1 & 0.03 & 33.3 & 2005.5 \\
\hline Artificial pond in Cave 2 & 0.04 & 25.0 & 2005.5 \\
\hline Percorating water in Cave 2 & 0.05 & 20.0 & 2005.5 \\
\hline Artificial pond in Cave 3 & 0.07 & 14.3 & 2005.5 \\
\hline Artificial pond in Cave 4 & 0.04 & 25.0 & 2005.5 \\
\hline Artificial pond in Cave 5 & 0.05 & 20.0 & 2005.5 \\
\hline Artificial pond on Cave 2 & 0.02 & 50.0 & 2005.5 \\
\hline Qu River & 0.03 & 33.3 & 2005.5 \\
\hline
\end{tabular}

\section{$6 \cdot 1$ 概要}

\section{6 現地地盤比抵抗測定}

前章までに得られた調査結果を総括すると，

i. 衛星画像打よび地形図より，洞窟周辺には断層が 多く存在し，地下水の移動方向は南北である.

ii. 盆地全体に溜池が多く見られ，洞窟周辺に地下水 が集まっている。

iii. 洞窟砂岩の鉱物分析の結果，モンモリロナイト含 有量が多い洞窟 3 では地盤強度が低下している。

iv. 洞窟上部を中心に風化が進行しており，また洞窟 は地下水面下に存在する。

v. 洞窟内の水, 溜池, 忂江の水の比抵抗は, 全て $50 \Omega \mathrm{m}$ 以下の低比抵抗である。

これらの情報を基に，2004 年 9 月および 2005 年 9 月 の 2 回地盤比抵抗調査を実施した。現地ではまず，基礎 データとして龍游洞窟周辺に見られる露頭での原位置比 抵抗測定を行った。龍游洞窟周辺では，Fig. 4 からもわ かるように砂岩層や希に介在する礫岩層の露頭が観察で きる。そのうちの数箇所を選定，測定した。

また，測線は現在観光用に公開されている，洞窟 1 5 周辺地盤を対象に設置した。前述の情報から，洞窟北 側地盤や洞窟 3 周辺を対象とし，測線を選定した。比抵 抗測定には, McOHM Profiler-4（OYO 製）を使用した。

\section{$6 \cdot 2$ 原位置比抵抗測定}

現地露頭は，洞窟南側を流れる忂江沿岸に多く見られ， その中で砂岩層, 碟岩層, 崩壊前後の段丘磻層を選定し, 測定した。測定方法は，四極法（Wenner 法）を用い， 電極間隔 $0.25 \mathrm{~m}$ とし，得られた比抵抗を露頭表面の比抵 抗と定義する。また露頭は風化を受けて抢らず，比較的 新鮮であると言える. Table 4 に測定結果を示す。

Table 4 より, 各表層土の比抵抗は, 砂岩層で 38.0 〜 $75.7 \Omega \mathrm{m}$ ，礫岩層で $79.3 \sim 111.0 \Omega \mathrm{m}$ ，段丘礫層で 196.4 $214.8 \Omega \mathrm{m}$ であった. 第三系の砂岩・礫岩の比抵抗が 100 〜 $1000 \Omega \mathrm{m}$ であることを考えれば，龍游洞窟を構成する砂 岩は低比抵抗であることがわかる。

\section{$6 \cdot 3$ 周辺地盤比抵抗調查概要}

比抵抗測線の選定において，人工物や舗装面を避け， ほぼ直線となるように測線を設置した。電極配置は，遠 電極設置が困難であること, 地盤浅部の詳細なデータが 必要であることから，四極法（Wenner 法）配置で測定 した。また，洞窟が全て地表から深度 $30 \mathrm{~m}$ 以内に存在す ることから，各測線で十分な探査深度を確保できるよう 電極間隔を決定した，現地データの検討は，表計算ソフ 卜上での減衰曲線補正を行ったのち, 逆解析ソフト上で の地形補正，スムージングを行った。逆解析には，比抵

Table 4 Results of In-situ Resistivity Measurement.

\begin{tabular}{|c|c|c|c|}
\hline$(\Omega \mathrm{m})$ & no.1 & no.2 & no.3 \\
\hline sandstone layer & 75.7 & 54.7 & 38.0 \\
\hline conglomerate layer & 111.0 & 79.3 & \\
\hline terrace gravel layer & 196.4 & 214.8 & \\
\hline
\end{tabular}


抗映像法解析プログラム『Elec Imager/2D』(OYO 製) を用いた。

地形図に地下洞窟位置を合成し，その図に，測線位置 をプロットしたものを Fig. 6 に示す. Fig. 6 には前章で 述べたボーリング調査位置も同様に示す。また，Fig. 6 のX-Y に打ける窟の断面と地層図を Fig. 7 に示す. Fig. 7 には, 洞窟位置に加え, ボーリング調査から得た地下水 位面 (GL) を示す。

地盤比抵抗を考察する上で，参考とする既往の研究 ${ }^{5)}$ について述べる，朴ら (1998) は，岩石が風化して，粘土 鉱物などを含んでいる場合，岩石比抵抗は間隙水比抵抗 よりも岩石構成物質の比抵抗に大きく影響されると報告 している. また，地下水の比抵抗が $20 \sim 80 \Omega \mathrm{m}$ の範囲で

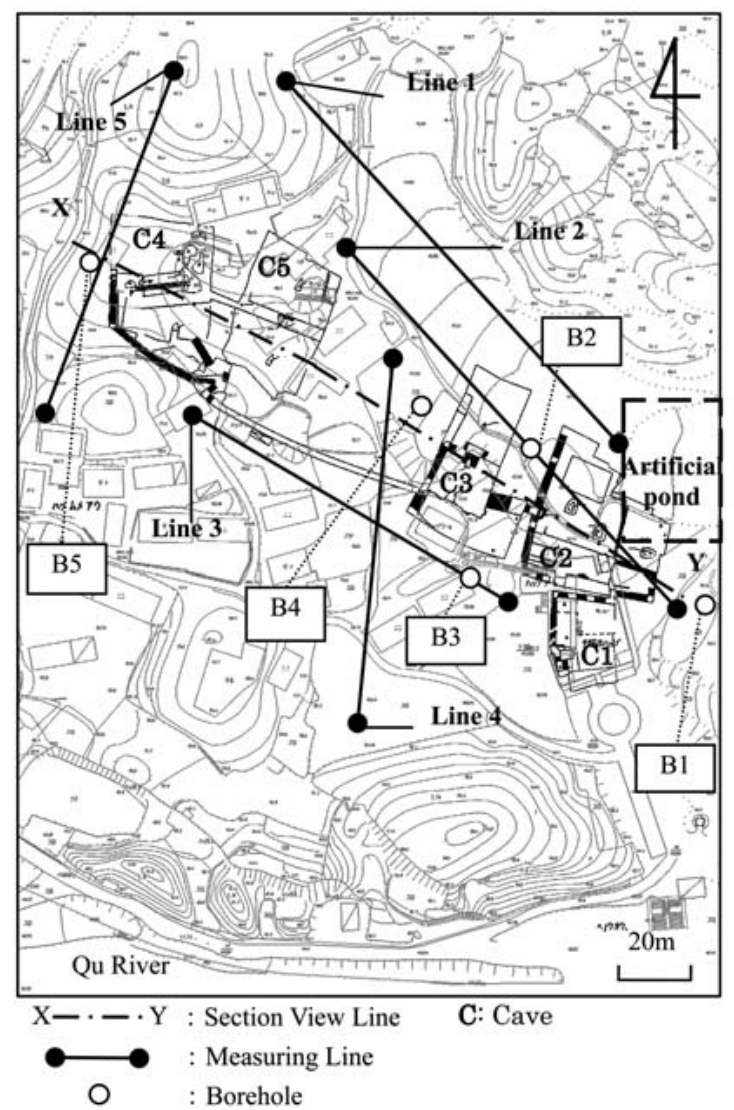

Fig. 6 Measuring lines and Boreholes on Topography with Plane Figure of 5 Caves.

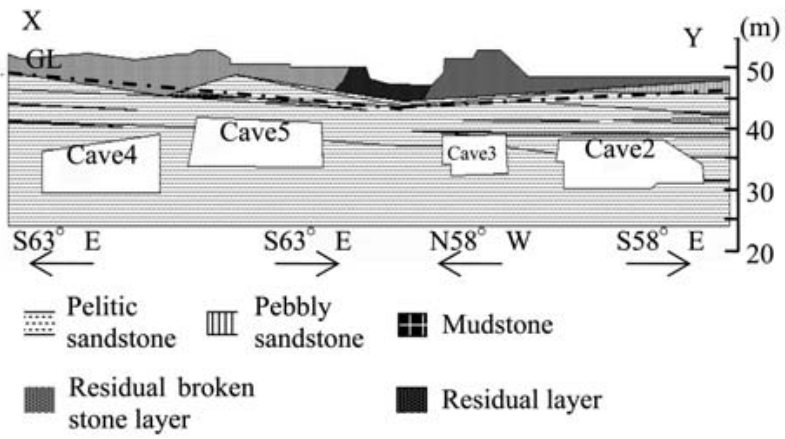

Fig. 7 Section view of 4 caves and geological layer along the line X-Y.
は, 間隙水の比抵抗変化による岩石の比抵抗変化があま り見られないことも述べている。これは，千葉ら (1994) の試験結果 ${ }^{2}$ や，関根ら (1997) の試験結果 ${ }^{9)}$ からも同様 の傾向が観察される関係である。粘土鉱物含有量が多く, 地下水面下は $50 \Omega \mathrm{m}$ 以下の比抵抗の水で飽和状態にある 可能性が高い龍游地盤は，この条件に当てはまる。つま り，地盤比抵抗は地下水の比抵抗に因らず，鉱物量やそ の他の要因によって左右されることが考えられる。

\section{6・4 Line 1 および Line 2 調査結果}

洞窟北側の地盤比抵抗調査のために, Line 1 および Line 2 を Fig. 6 に示す位置に設置した. Line 1 設置箇所 は洞窟北側の平地で，東西に人工的な盛土がある。また， Line 2 は洞窟上部に設置し, 洞窟 2 および洞窟 3 近辺の 地盤特性の把握と, Line 1 との比較を行う。洞窟 2 の上 部には, 約 $400 \mathrm{~m}^{2}$, 水深約 $2 \mathrm{~m}$ 程度の溜池が造成されて おり, Table 3 の Artificial pond on Cave2 よりその比抵抗

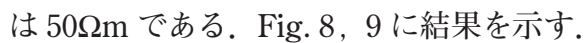

Line 1 の結果を示す Fig. 7 より，3 号窟北側の地盤は 全体的に低比抵抗であり，変化に乏しい。これは，地下 水面前後で比抵抗が急激に変化するような地盤 ${ }^{10)}$ とは大 きく異なる．得られた地盤比抵抗が飽和地盤のそれを表 すと考えると, 比抵抗の高低は地下水の比抵抗の影響と は考えにくい.

測線南東部，洞窟 3 の北側に打いて $10 \Omega \mathrm{m}$ 程度の低比 抵抗帯（図中(1)）が存在する，5・2 節より，砂岩露頭の 比抵抗が $38 \sim 75.7 \Omega \mathrm{m}$ であることを考えると, (1)付近に は粘土鉱物，特にここではモンモリロナイト等の存在に よる地盤強度の低下（風化）という，比抵抗を下げる要 因が考えられる。これは $\mathbf{6} \cdot \mathbf{1}$ 節 iii に示す鉱物分析の結 果と対応させて考察することができる。また，罒からは (2)の低比抵抗の西へ落ちる傾斜が確認できる.

Fig. 9 の Line 2 の比抵抗分布では, 空洞である洞窟 2

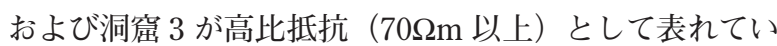
る。これは, 龍游地盤のような地下水面の高い地盤でも， 地下空洞を探査できることを意味し，龍游の地盤比抵抗 分布に打いて，洞窟は $70 \Omega \mathrm{m}$ 以上を示すと言える。 B2 の ボーリング結果を併せると, 洞窟付近は強〜弱風化層で あり，地表付近の人口盛土は高比抵抗として表れている.

また，洞窟上部の深度 $5 \mathrm{~m}$ 程度のあたりに低比抵抗帯 が見られる (図中(3))。これは，2 号窟上部の溜池の位置 に相当する。これまでの地盤特性から, 溜池の水の比抵 抗の影響ではなく，溜池の水が地盤に浸透し，地盤を構 成する砂岩が風化し，粘土鉱物が増加することにより， 低比抵抗を表していると考えるのが妥当である。これは 洞窟 2,3 の天井部にあたり，6・1 節 iv にも一致する結 果である。このことから, 洞窟の天井部に溜池からの水 の流入があると言える。また，Fig. 8 同様，(2)の比抵抗 の西へ落ちる傾斜が確認できる，2測線の連続性から， 同傾斜の断層や割れ目が存在すると考えられ，北西一南 東方向に走行している。iを考慮すると，広域同様，洞 窟周辺にも南北に走行する割れ目が存在する可能性が考 えられる。 


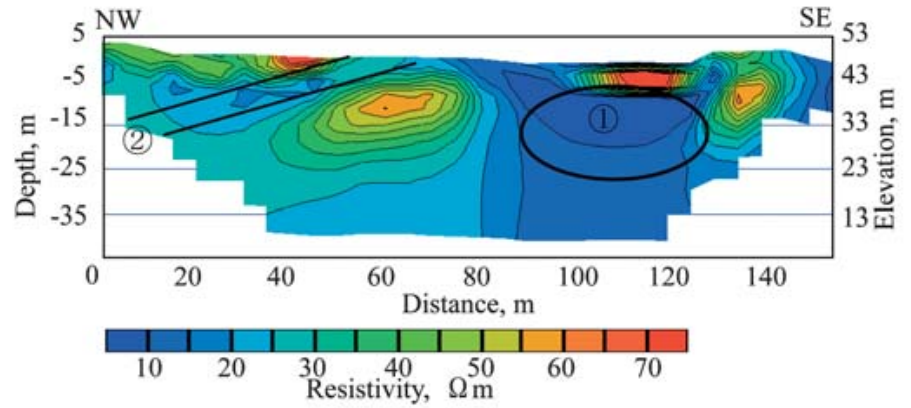

Fig. 8 Resistivity Distribution of Line 1.



Fig. 9 Resistivity Distribution of Line 2.

洞窟 3 周辺の低比抵抗帯(1)ついて，モンモリロナイ 卜含有量が関連していることを述べたが，モンモリロナ イトによる比抵抗の低下は地盤の風化による比抵抗の低 下を意味する。この龍游地盤の風化は地下水の存在に起 因する。つまり, 洞窟 3 周辺地盤は, 地下水が豊富に存 在し，周辺からの水の流入が多いことが考えられる.

\section{6・5 Line 3 および Line 4 調査結果}

次に洞窟 3 南側に設置した Line 3 および，洞窟 3 の 西側において，南北方向の地盤比抵抗特性を把握するた めに設置した Line 4 の結果を考察する.

現地踏査から, 洞窟 3 の西壁には目視で確認できる割 れ目が多数存在し，地下水の流入が観察できた。 2 測線 の結果は，粘土鉱物や割れ目の影響を受けている可能性 が考えられる. Fig. 10，11にLine 3 およびLine 4 の調 査結果を示す。

Fig. 10 より，洞窟 3 の南側にあたる図中(4)が $20 \Omega \mathrm{m}$ 以下と比抵抗が低くなっている。これは Fig. 8 の(1)同 様，洞窟 3 周辺地盤のモンモリロナイト等の存在による 地盤の風化が影響しているものと考えられる．B3 のボー リング結果からは，この付近は弱風化層であり，一様に 泥質砂岩層が続いている.

Line 4 の比抵抗分布を示す, Fig. 11 より, Fig. 10 同 様 $20 \Omega \mathrm{m}$ 以下の低比抵抗帯が測線南側に分布している. Fig. 10 の Line 3 との位置関係から, 洞窟 3 南側の低比 抵抗帯(5)を表していると推測される。

また，洞窟 3 西側地盤を表す(6)は(1)や(5)に比べて比抵 抗がやや高く $40 \Omega \mathrm{m}$ 程度である. 洞窟 3 の西壁の割れ目や 地下水の流入を考えると，破砕帯等の要因が考えられる.

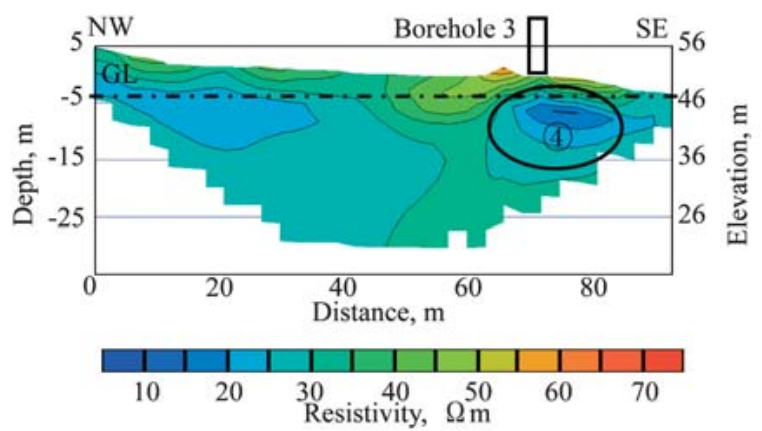

Fig. 10 Resistivity Distribution of Line 3.
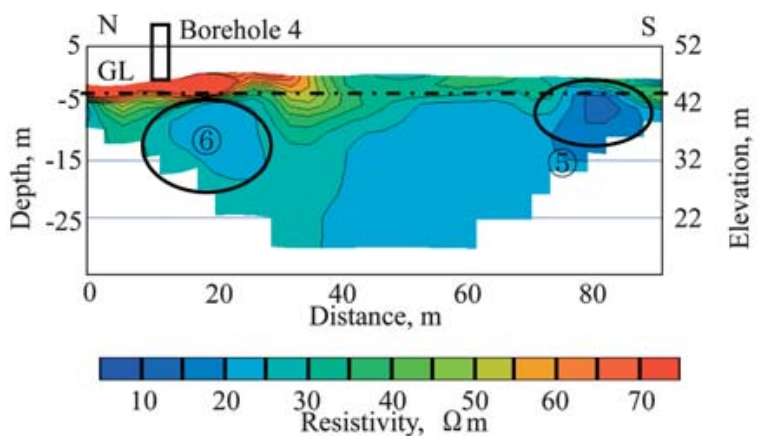

Fig. 11 Resistivity Distribution of Line 4.

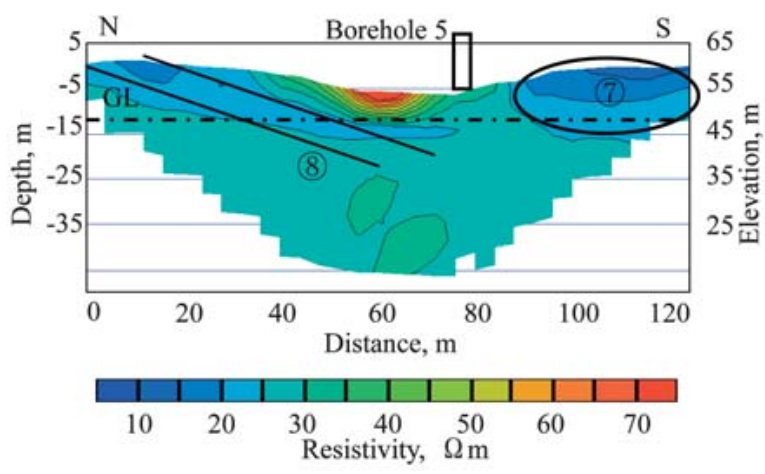

Fig. 12 Resistivity Distribution of Line 5.

\section{6・6 Line 5 調査結果}

洞窟 4 および洞窟 5 でも天井からの漏水が確認されて おり，洞窟 3 と同様に今後砂岩の風化が進行する可能性 が考えられる。そこで，Line 5 を洞窟 4 上部地盤に南北 に設置し，洞窟西側地盤の比抵抗特性を把握する. Fig. 12 に Line 5 の調査結果を示す.

Line 5 設置箇所は他の測線に比べ，標高が高く，高低 差が大きい．Fig．12 より，表層部の盛土と考えられる部 分が高比抵抗ではあるが，ほぼ均質な比抵抗分布となっ た。洞窟 4 周辺も均質に地下水が分布し，洞窟に影響を 及ぼしていると考えられる。(7)が示す $20 \Omega \mathrm{m}$ 以下の表層 部の低比抵抗帯は，強風化層であると考えられるが，定 量的には断定できない. また，8が示す比抵抗の傾斜は， 洞窟 4 の天井の傾斜（約 $\mathrm{S} 30^{\circ} \mathrm{N}$ ） と針角に交わる傾斜で ある．洞窟天井部に交わるような南へ傾斜する割れ目や 断層破砕帯が洞窟 4 周辺に存在すると考えられ，他の洞 窟周辺の割れ目との整合性は確認できないが，天井部へ の割れ目の原因となり得る. 


\section{7 結}

\section{言}

以上, 本研究で述べた龍游洞窟の地盤比抵抗特性の考 察を以下にまとめる。

（1）洞窟地盤は, 飽和状態にあると考えられ, 地盤比 抵抗は変化に乏しいが, 地下空洞は探査可能であり, 龍游 地盤では $70 \Omega \mathrm{m}$ 以上の比抵抗は洞窟を表すと考えられる.

（2）洞窟 3 周辺には，低比抵抗帯が多く見られ，これ は洞窟 3 の構成砂岩が, モンモリロナイトにより風化し ているという鉱物分析の結果と一致する.

(3) Line 1，2 の低比抵抗帯より, 洞窟 2, 3 の天井 部には地表や北側地盤からの水の流入が多いことが言え， ボーリング調査からわかる風化層や天井部の水の浸透現 象に関連している。

（4）低比抵抗帯の傾斜から, 割れ目や地層の傾斜を判 別できると考えられる.

本研究は, 飽和状態にある砂岩層地盤の比抵抗特性と 遺跡保存のための比抵抗探査の活用という二つの観点か ら研究を進めている．龍游地盤比抵抗と周辺の地盤情報 との関連性が論ぜられたことは，前者にとって大きな成 果である.

後者については, 水を排水してしまった五つの洞窟に ついて, 地下水の影響や風化状態などを把握する必要が ある. 本論では, 人口の溜池から洞窟への水の流入が視 覚的に捉えることができるなど，比抵抗調査から洞窟の 地盤状況について提言できた。 今回考察を行った調査結 果は，年に一度の継続的な調査の結果であり，今後龍游 洞窟を保存していくために, 地盤の比抵抗特性を把握し ていくことは必要である。比抵抗探査は本研究の重要な 役割を担っていると言える.

中国における現地調査に多大の支援を受けた龍游洞窟 管理局の関係者並びに，調査参加者の諸氏に対し，深甚 の謝意を表する。

\section{参 考 文 献}

1) T. Sakayama, "Examples of archaeological Investigations using geophysical surveys", Butsuri-tansa, Vol.44, No.6, pp.412418 (1991).

2) A. Chiba and M. Kumata, "Resistivity measurement for granite and tuff samples”, Butsuri-tansa, Vol.47, No.3, pp.161172 (1994).

3) H. Kameya and K. Sakurai, "Resistivity measurement for rock samples and permeability estimation”, The 11th Japan National Symposium for Rock Mechanics 2002, E05, (2002).

4 ) K. Nishida and H. Kawakami, "Influence of pore water resistivity on rock resistivity characteristics and applicability of equivalent parallel circuit model”, Butsuri-tansa, Vol.53, No.2, pp.167-181 (2000).

5 ) S. Park and T. Matsui, "Basic study on resistivity of rocks", Butsuri-tansa, Vol.51, No.3, pp.201-209 (1998).

6) $\mathrm{Li} \mathrm{Li}$, "A study on the weathering characteristics of sandstone around the Longyou Grottoes of China”, Doctoral dissertation of Graduate School of Eng., Osaka Univ. (2005).

7) The Japanese Geotechnical Society, "Tsuchi- nosikenzissyusyo", p.20 (1996).

8 ) T. Sudo, “Clay mineralogy”, pp.13-40 (1974) Iwanami Shoten.

$9)$ I. Sekine, H. Nishimaki, K. Ishigaki, T. Hara and A. Saito, "Consideration of electric surface conduction for determining the correlation between rock resistivity and elastic wave velocity", Journals of the Japan Society of Civil Engineers, No.568, III-39, pp.209-219 (1997).

10) C. Tanimoto and K. Koizumi, "Summarized Activity of Osaka University Dunhuang Mission”, Tsuchi-to-kiso, Vol.53, No.3 (2005). 